\title{
Uterine histology and prostaglandin concentrations and utero-ovarian venous steroid and prostaglandin concentrations during the luteal phase of the menstrual cycle in baboons (Papio spp.) with or without an IUD
}

\author{
A. G. Wheeler*, P. R. Hurst†, N. L. Poyser $\ddagger$ and P. Eckstein \\ Department of Anatomy, Medical School, University of Birmingham, Vincent Drive, \\ Birmingham B15 2TJ and $\ddagger$ Department of Pharmacology, University of Edinburgh, \\ 1 George Square, Edinburgh EH8 9JZ, U.K.
}

\begin{abstract}
Summary. Arachis oil was infused via the oviducts into the uterus of baboons 6-9 days after ovulation; uterine tissue was collected towards the end of the luteal phase (3-7 days after the oil infusion) for histological assessment of the occurrence of any deciduomal reaction. To exclude the possibility that a variation in the endogenous steroid concentrations was responsible for any observed variation in the incidence of the deciduomal reaction, blood samples were collected and assayed for progesterone and oestradiol-17 7 . The effect of the IUD on endometrial prostaglandin release was examined by measuring PGE and PGF concentrations in uterine tissue and utero-ovarian venous plasma.

The IUD stimulated a deciduomal response in every animal, whereas the traumatization with arachis oil had no such effect; the variation in the peripheral and uteroovarian steroid levels could not explain the variation in the incidence of the deciduomal reaction. Greater concentrations of PGF but not PGE were present in the endometria of those animals bearing an IUD and in which a deciduomal reaction had been stimulated.

The corpus luteum was the major source of progesterone and of oestradiol-17 $\beta$, although non-luteal ovarian tissue also secreted oestradiol-17 $\beta$.
\end{abstract}

\section{Introduction}

Baboons fitted with an intrauterine device (IUD) menstruate when there is a higher $(1.51 \mathrm{ng} / \mathrm{ml})$ peripheral plasma progesterone concentration than do baboons without such a device $(0.60 \mathrm{ng} / \mathrm{ml}$; Breed, Stephenson, Eckstein, Peplow \& Butt, 1972), indicating that the IUD may alter the sensitivity of the uterine endometrium to circulating progesterone, as it does in rats (Psychoyos, 1966; Chaudhury \& Sethi, 1970) and mice (Martin \& Finn, 1970). Marston, Kelly \& Eckstein (1971) found that the injection of arachis oil into the oviducts traumatized the uterine endometrium, stimulating a deciduomal reaction similar to the epithelial plaque formed during implantation in

* Present address: Department of Physiology and Pharmacology, University of Queensland, St Lucia, Queensland, Australia 4067.

† Present address: Department of Anatomy, The Medical School, University of Otago, P.O. Box 913, Dunedin, New Zealand. 
non-IUD and IUD-bearing rhesus monkeys with and without exogenous progesterone. However, the administration of exogenous progesterone alone (10 $\mathrm{mg}$ daily) was sufficient to result in a deciduomal reaction in IUD-bearing rhesus monkeys. The present study was designed to investigate the effect of the IUD on the sensitivity of the uterine endometrium to circulating steroids by examining the occurrence of the deciduomal reaction in response to arachis oil traumatization of the uterine endometrium in intact, cyclic non-IUD and IUD-bearing baboons with known endogenous progesterone and oestradiol-17 $\beta$ concentrations. These concentrations were measured in peripheral blood samples as these would be comparable to the concentrations in the uterine arterial supply.

Chaudhuri (1971) has suggested that one of the antifertility effects of the IUD is produced by the stimulation of a mild trauma of the uterine endometrium causing the release of prostaglandins (PG) which prevent conception. We therefore also collected utero-ovarian venous plasma and uterine tissue samples for the assay of PGE-2 and PGF-2 $\alpha$ to determine whether the presence of an IUD in baboons causes an elevation of PG concentrations.

The concentrations of progesterone and oestradiol- $17 \beta$ in the utero-ovarian venous plasma were measured to determine whether either of the treatments, IUD and uterine endometrium traumatization, affected the ovarian secretion of steroids. These data also permitted elucidation of the source of these steroids.

\section{Materials and Methods}

\section{Experimental animals}

The animals used were taken from a group of about 40 adult, mature baboons (Papio anubis, $P$. cynocephalus, $P$. papio and $P$. ursinus) maintained within the department, the management being similar to that described for rhesus monkeys by Eckstein, Kelly \& Marston (1969). They were observed daily for the appearance of menstrual blood on the perineum, and the size and colour of the sex skin was assessed subjectively (Breed et al., 1972). The typical variation in the 'sex skin score' during a menstrual cycle, shown in Text-fig. 1, is similar to that described by Breed et al. (1972). The IUDs, shortened Margulies Spirals (polyethylene about $0.1 \mathrm{~cm}$ thick and $2 \mathrm{~cm}$ diameter), were inserted via a puncture wound through the uterine wall during laparotomy under halothane- $\mathrm{O}_{2}$ anaesthesia at least 5 weeks before the onset of the menstrual cycle in which the experiment was performed; the presence of the IUD was subsequently checked by radiography.

Arachis oil traumatization of the uterine endometrium, or a sham procedure, was usually performed 6-9 days after presumed ovulation (considered to have occurred 2 days before the onset of detumescence; Breed et al., 1972); details of the timing of the procedures for each animal are given in Table 1. At laparotomy under halothane- $\mathrm{O}_{2}$ anaesthesia, arachis oil, $2 \mathrm{ml}$ per oviduct, was injected slowly through a rounded 21 -gauge hypodermic needle inserted through the ostium and held in place with artery forceps with rubber tubing on the prongs to protect the oviduct. The location of the corpus luteum was recorded and a peripheral blood sample was obtained from the femoral vein. The sham procedure was similar in all respects except that no arachis oil was injected.

A peripheral blood sample was obtained 2-5 days later from the femoral vein. Ketamine hydrochloride ( $10 \mathrm{mg}$ i.m., Vetalar, Parke-Davis) was used to sedate the animals for this procedure, as with all the procedures requiring the handling of the baboons.

A third peripheral plasma sample was collected from the femoral vein 3-6 days after stimulation of the uterine endometrium, or a sham procedure, i.e. during the late luteal period. Then, under halothane- $\mathrm{O}_{2}$ anaesthesia, a laparotomy was performed and the reproductive tract exposed. Blood samples were collected from the channels of the utero-ovarian vein (Ginther, Dierschke, Walsh \& Del Campo, 1974) on each side, care being taken not to handle the reproductive tract excessively to avoid prostaglandin release as a result of tissue damage (Greenwood \& Kerry, 1975). When collection of the utero-ovarian blood samples was difficult, the attempt was curtailed or abandoned 
rather than prolong the handling of the reproductive tract and possibly stimulate PG secretion; this accounts for the missing utero-ovarian PG and steroid concentrations in Tables 2 and 3 . The ovaries and uterus were then removed from the abdomen and the uterus transected to expose the endometrial cavity. The position of the IUD, if present, was noted and large pieces of tissue the full depth of the uterine wall from the dorsal and lateral aspects were placed in Bouin's fluid for histological examination. Samples of uterine endometrial tissue were stored in $10 \mathrm{ml}$ ethanol at $-20^{\circ} \mathrm{C}$ until assayed for PGs. Approximately $30 \mathrm{~min}$ after the removal of the ovaries and uterus blood samples were collected from the femoral vein and the femoral artery.

All blood samples were withdrawn into heparinized syringes, transferred to heparinized tubes and stored in iced water until centrifuged $\left(900 \mathrm{~g}_{\mathrm{av}}, 4^{\circ} \mathrm{C}, 30 \mathrm{~min}\right)$. The plasma was then stored in aliquots at $-20^{\circ} \mathrm{C}$ until assayed. Care was taken to cool the blood immediately after collection and to minimize the delay before centrifugation to limit any changes in the plasma PG concentrations due to metabolism by the blood cells (Challis \& Tulchinsky, 1974).

Three baboons were excluded from the experiment after the collection of the blood and tissue samples on the final day of the procedure; one had a uterus with an abnormal (lumpy) appearance and an IUD in the uterine lumen, in one the IUD was located in the cervical lumen and in the third animal the IUD was embedded in the wall of the cervix.

\section{Histology of uterine tissue}

Transverse sections $(7 \mu \mathrm{m})$ were stained with haematoxylin and eosin or by the PAS method. Slides were coded and sections examined for the presence, extent and location of deciduomal tissue.

\section{Hormone assays}

Progesterone concentrations. The plasma samples were assayed for progesterone using the radioimmunoassay method and antiserum (91920/9) described by Scaramuzzi, Corker, Young \& Baird (1975). Repeated assay of plasma pools gave mean \pm s.e.m. values of $5 \cdot 34 \pm 0 \cdot 20 \mathrm{ng} / \mathrm{ml}(n=21)$ for baboon plasma. The intra- and inter-assay coefficients of variation were 8.8 and $16.3 \%$ respectively. Known amounts of progesterone were added to ptasma from an ovariectomized baboon to give concentrations of $0,0 \cdot 5,1,2,5$ and $10 \mathrm{ng} / \mathrm{ml}$, and these samples were included in each assay. The regression equation was $y=0.62+1.02 x$ (where $y$ is the measured progesterone concentration and $x$ the added progesterone concentration) and the sample deviation of the regression coefficient was $0.019\left(t_{(4)}=53.74, P<0.001\right)$ (Snedecor \& Cochran, 1967). The typical variation in the peripheral plasma progesterone concentration measured during the menstrual cycle, shown in Text-fig. 1, is similar to that described by Stevens, Sparks \& Powell (1970) and Breed et al. (1972).

Oestradiol-17 $\beta$ concentrations. These were determined by radioimmunoassay, using the antiserum OR-422/7, described by Scaramuzzi et al. (1975). Plasma samples ( $500 \mu \mathrm{l})$ were extracted by vortexing for $30 \mathrm{sec}$ with $2 \mathrm{ml}$ re-distilled diethyl ether. The aqueous phase was frozen and the diethyl ether tipped into a second tube, dried under nitrogen and the solutes re-dissolved in phosphate-buffered saline containing gelatin $(0 \cdot 1 \% \mathrm{w} / \mathrm{v})$ and sodium azide $(0 \cdot 1 \% \mathrm{w} / \mathrm{v})$. Aliquots of the standard solutions of oestradiol-17 $\beta$ (Steraloids) in alcohol were similarly evaporated and redissolved in buffer. Then $100 \mu$ of $1: 30000$ dilution of the antiserum were added and the tubes incubated at room temperature for $30 \mathrm{~min}$ before the addition of tritiated oestradiol-17 $\beta$ $\left([2,4,6,7(\mathrm{n}))^{3} \mathrm{H}\right]$ oestradiol; $354 \mathrm{mCi} / \mathrm{mg}$; Radiochemical Centre, Amersham; 5000 c.p.m. per tube). The tubes were incubated overnight at $4^{\circ} \mathrm{C}$ before separation of the bound and free steroid by exposure to $1 \mathrm{ml}$ dextran-charcoal mixture in phosphate-gelatin buffer $(0.025 \%$ and $0.25 \% \mathrm{w} / \mathrm{v}$ respectively) for $15 \mathrm{~min}$ at $4^{\circ} \mathrm{C}$ before centrifugation. The supernatant was tipped into scintillation vials for determination of the radioactivity. The assay data were computed using a programme originally derived from that of Rodbard \& Lewald (1970). 


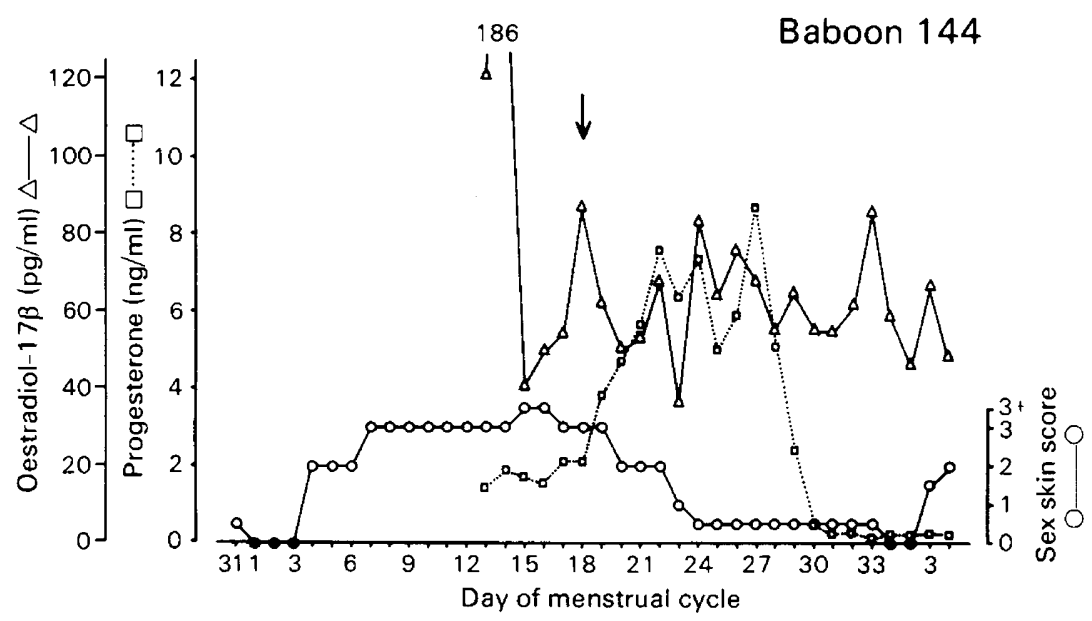

Text-fig. 1. Variation in the 'sex skin score' (see text) and peripheral plasma progesterone and oestradiol-17 $\beta$ concentrations during a typical menstrual cycle in a non-IUD-bearing baboon (No. 144). Arrow indicates presumed day of ovulation. indicates the days on which menstrual bleeding was observed. Day 1 is the first day of menstruation.

The efficiency of the extraction procedure, assessed by the extraction of plasma containing tritiated oestradiol $-17 \beta$, was usually between 80 and $90 \%$. The minimum detectable dose was about $5 \mathrm{pg}$ per tube (about $12 \mathrm{pg} / \mathrm{ml}$ plasma). The repeated assay of plasma from an ovariectomized baboon to which oestradiol- $17 \beta$ had been added to give concentrations of $0,50,100,200$ and $500 \mathrm{pg} /$ $\mathrm{ml}$ gave a regression equation of $y=11.24+1 \cdot 109 x$ (where $y$ is the measured oestradiol-17 $\beta$ concentration and $x$ is the added oestradiol-17 $\beta$ concentration) and the sample standard deviation of the regression coefficient was $0.171\left(t_{(3)}=6.47, P<0.01\right)$. Repeated assay of aliquots of a pool of baboon plasma gave mean \pm s.e.m. values of $239.5 \pm 5.5(n=8) \mathrm{pg} / \mathrm{ml}$ and mean intra- and interassay coefficients of variation of 6.53 and $7 \cdot 17 \%$ respectively.

The variation in the oestradiol- $17 \beta$ concentration measured during a typical menstrual cycle is shown in Text-fig. 1.

Tissue PG concentrations. One endometrial sample from each baboon was weighed and homogenized in the alcohol in which it had been stored using a Fison's glass homogenizer. After centrifugation, the supernatant was withdrawn. The precipitate was washed with $5 \mathrm{ml}$ absolute alcohol, centrifuged and the supernatant combined with the original extract. Each extract was evaporated to dryness under reduced pressure at $45^{\circ} \mathrm{C}$. Each residue was dissolved in $15 \mathrm{ml}$ water, adjusted to $\mathrm{pH} 4.5$ with $1 \mathrm{~N}-\mathrm{HCl}$ and the prostaglandins extracted by partitioning three times with $30 \mathrm{ml}$ re-distilled ethyl acetate. The ethyl acetate extract was evaporated to dryness as above, and the residue re-dissolved in $10 \mathrm{ml}$ re-distilled ethyl acetate and stored at $-20^{\circ} \mathrm{C}$ until assayed. The PGE and PGF contents were determined using radioimmunoassays which have previously been described (Poyser \& Scott, 1980). The amounts of PGE and PGF in $100 \mathrm{mg}$ endometrial tissue were calculated.

Plasma PG concentrations. Plasma samples $(0.1$ and $0.2 \mathrm{ml})$ were assayed in duplicate for PGF$2 \alpha$ by a radioimmunoassay using methods previously described (Blatchley \& Poyser, 1974). When the quantity of PGF- $2 \alpha$ present exceeded the upper limit of the assay, the plasma sample was diluted 10 times with water and the assay repeated. When the quantity of plasma permitted, the level of PGE-2 in each sample was also determined by radioimmunoassay in a similar manner.

For the PGE-2 assay the detection limit was 5 pg per tube, the intra-assay coefficient of variation was $9 \cdot 8 \%$ (calculated from the variation between the duplicate results obtained for each 


\section{PLATE 1}

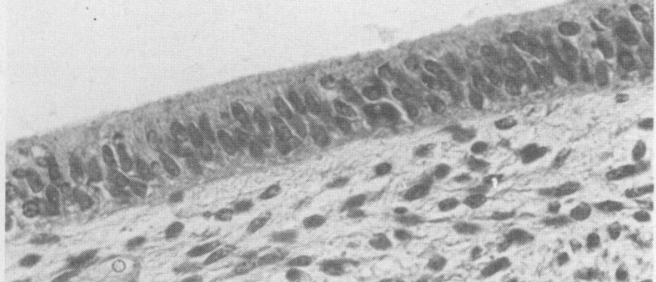

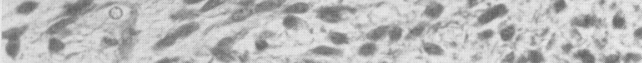

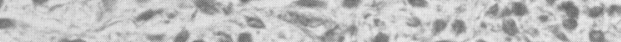

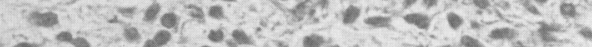

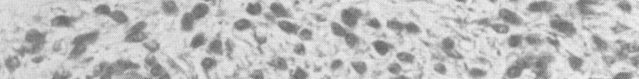

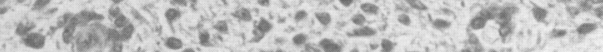

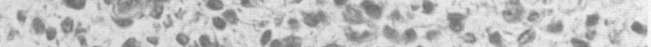

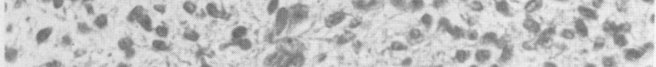

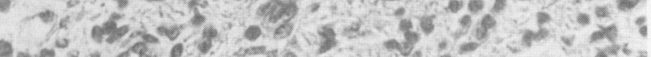

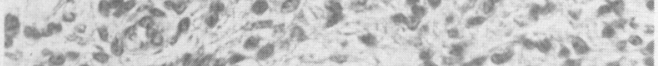

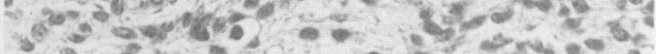

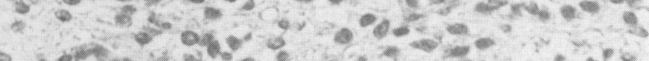
$1,100-5=$

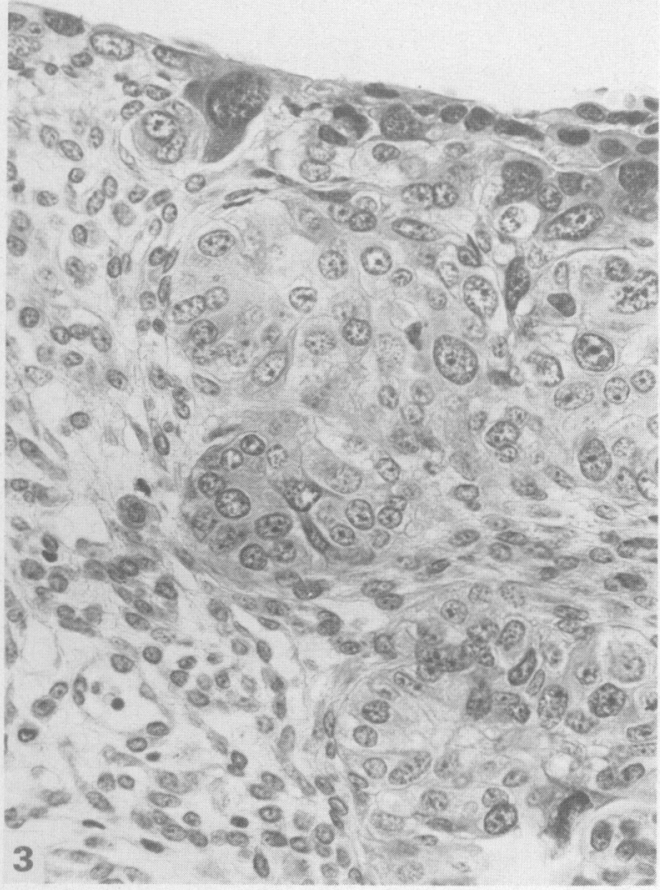

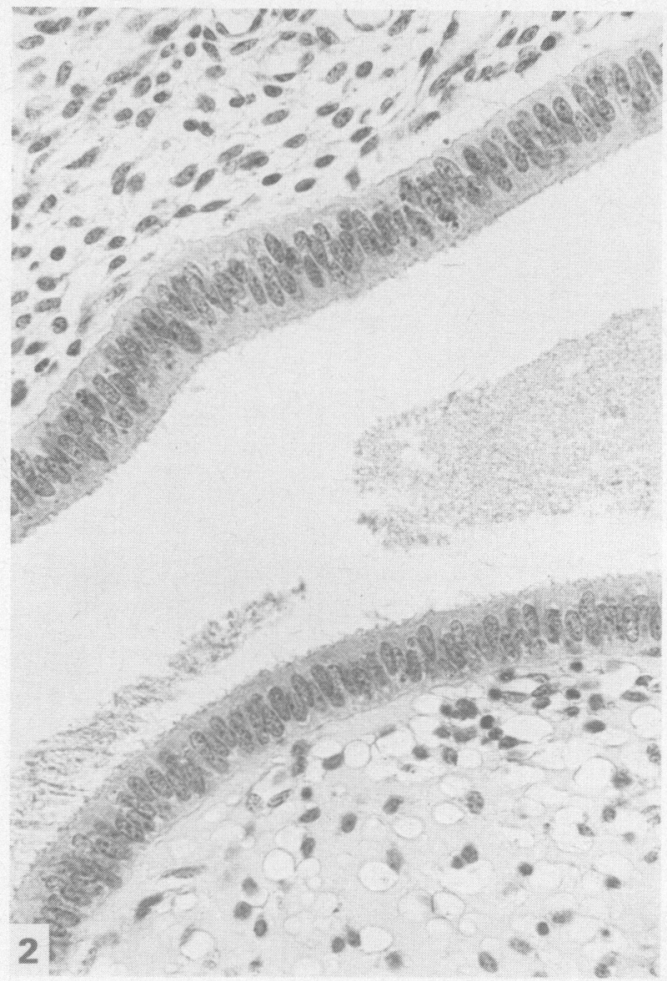

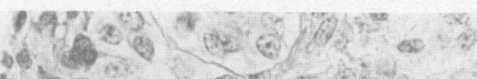

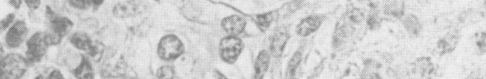

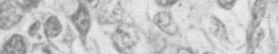

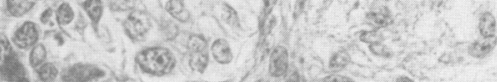

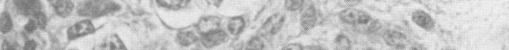

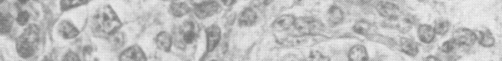

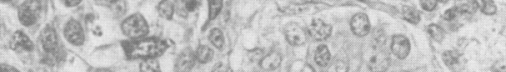

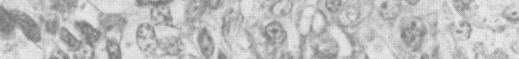
1.62. a

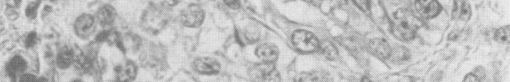

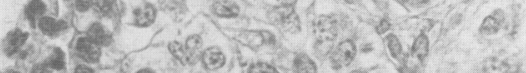

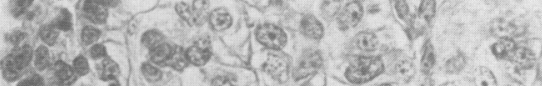

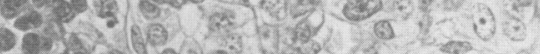

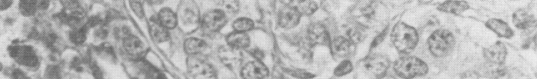
E.

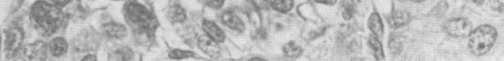

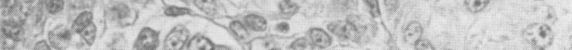

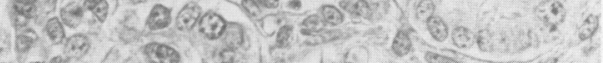
a (3) 40.50 4 (s) 
biological sample) and the inter-assay coefficient of variation was $10 \cdot 1 \%$ (calculated from the result obtained by incorporating a known quantity of $20 \mathrm{pg}$ PGE-2 in each assay). For the PGF-2 $\alpha$ assay the detection limit was $40 \mathrm{pg}$ per tube, the intra-assay coefficient of variation (calculated as for the PGE-2 assay) was $11.9 \%$ and the inter-assay coefficient of variation (calculated as for the PGE-2 assay but using $160 \mathrm{pg}$ PGF-2 $\alpha$ ) was $8.7 \%$.

\section{Statistics}

The results were assessed by analysis of variance, Student's $t$ test and paired Student's $t$ tests as appropriate.

\section{Results}

Histology of uterine tissue

Control uteri. All sections observed from each specimen revealed a typical progestational endometrium; no decidualizing cells were evident (Pl. 1, Fig. 1).

Table 1. Details of the date of insertion, uterine traumatization, tissue collection and preceding menstrual cycle durations for each baboon

\begin{tabular}{|c|c|c|c|c|c|c|}
\hline \multirow[b]{2}{*}{ Treatment } & \multirow[b]{2}{*}{$\begin{array}{c}\text { Baboon } \\
\text { no. }\end{array}$} & \multirow[b]{2}{*}{$\begin{array}{l}\text { Date of IUD } \\
\text { insertion }\end{array}$} & \multirow[b]{2}{*}{$\begin{array}{c}\text { Duration of earlier } \\
\text { menstrual } \\
\text { cycles (days) }\end{array}$} & \multirow[b]{2}{*}{$\begin{array}{l}\text { Date of onset of } \\
\text { pre-experimental } \\
\text { menstruation }\end{array}$} & \multicolumn{2}{|c|}{ Days after 'ovulation' $\dagger$} \\
\hline & & & & & $\begin{array}{l}\text { Arachis oil } \\
\text { (or sham) } \\
\text { injection }\end{array}$ & $\begin{array}{c}\text { Tissue } \\
\text { collection }\end{array}$ \\
\hline Control & $\begin{array}{r}55 \\
57 \\
64 \\
153\end{array}$ & $\begin{array}{l}- \\
- \\
-\end{array}$ & $\begin{array}{l}34,31,36 \\
34,31,33 \\
27,29,29 \\
34,36,32\end{array}$ & $\begin{array}{r}20 \text { May } 1975 \\
4 \text { Jun. } 1975 \\
2 \text { May } 1975 \\
17 \text { Apr. } 1976\end{array}$ & $\begin{array}{l}2 \\
6 \\
9 \\
6\end{array}$ & $\begin{array}{r}6 \\
9 \\
12 \\
11\end{array}$ \\
\hline Traumatized uterus & $\begin{array}{l}154 \\
159 \\
165\end{array}$ & $\begin{array}{l}- \\
- \\
-\end{array}$ & $\begin{array}{l}32,62,32 \\
29,34,27 \\
39,34,42\end{array}$ & $\begin{array}{r}14 \text { Apr. } 1975 \\
21 \text { May } 1975 \\
5 \text { May } 1975\end{array}$ & $\begin{array}{l}9 \\
4 \\
7\end{array}$ & $\begin{array}{l}14 \\
10 \\
11\end{array}$ \\
\hline IUD fitted & $\begin{array}{l}152 \\
441 \\
610\end{array}$ & $\begin{array}{l}17 \text { Mar. } 1972 \\
22 \text { Nov. } 1975 \\
29 \text { Nov. } 1976\end{array}$ & $\begin{array}{r}47,48,44 \\
51 \\
45,31,51\end{array}$ & $\begin{array}{r}25 \text { May } 1975 \\
6 \text { Jan. } 1977 \\
7 \text { Jan. } 1977\end{array}$ & $\begin{array}{l}7 \\
8 \\
6\end{array}$ & $\begin{array}{l}10 \\
11 \\
12\end{array}$ \\
\hline $\begin{array}{l}\text { Traumatized uterus, } \\
\text { IUD fitted }\end{array}$ & $\begin{array}{r}63 \\
155 \\
156\end{array}$ & $8 \mathrm{Dec}_{*}^{*} 1972$ & $\begin{array}{r}32,31 \\
31,34,32 \\
36,38,41\end{array}$ & $\begin{array}{l}28 \text { Apr. } 1975 \\
18 \text { Jun. } 1975 \\
21 \text { May } 1975\end{array}$ & $\begin{array}{l}8 \\
6 \\
7\end{array}$ & $\begin{array}{l}12 \\
12 \\
13\end{array}$ \\
\hline
\end{tabular}

* Before February 1975.

$\dagger$ Presumed to have occurred 2 days before detumescence.

\section{PLATE 1}

Histology of the baboon endometrium in tissue samples representative of each of the four treatment groups. $\times 677$.

Fig. 1. Baboon 55, control: typical progestational uterine endometrium, no decidualizing cells evident.

Fig. 2. Baboon 165, traumatized uterus: typical progestational uterine endometrium indistinguishable from control tissue.

Fig. 3. Baboon 152, IUD: histology shows erosion of the endometrial surface and underlying decidualization.

Fig. 4. Baboon 156, IUD and traumatized uterus: surface erosion of the endometrium and underlying decidualization. 
Traumatized (oil-treated) uteri. In 2 of the 3 animals the uterine sections were indistinguishable from control tissue with no evidence of decidualization. In the 3rd animal (No. 159) occasional isolated epithelial cells were hypertrophied with large nuclei and were considered pre-decidual. Such cells were restricted to the surface epithelium and represented less than $0.1 \%$ of cells in this layer. The remaining epithelium was similar to that in of the control specimens (Pl. 1, Fig. 2).

IUD-fitted uteri. Areas of decidual tissue were located in sections from all 3 animals. Clusters of decidual cells including transformed glandular epithelia predominated in the lateral margins of the endometrial surface. In most sections the central regions of the endometrium showed extensive surface erosion and large numbers of leucocytes were seen in the underlying stroma. Occasional groups of decidual cells were present immediately beneath the erosion areas (Pl. 1, Fig. 3).

IUD-fitted, traumatized uteri. All tissue sections from these 3 animals revealed a pattern and extent of decidualization and erosion similar to that found in IUD-bearing baboons. In Baboon 156 there was a marked response with extensive stromal transformation (Pl. 1, Fig. 4).

\section{Steroid concentrations}

All the baboons except one (No. 155) had a peripheral progesterone concentration $>1 \mathrm{ng} / \mathrm{ml}$ (Table 2) during the period of traumatization of the uterus until tissue collection, indicative of a functional corpus luteum. In every animal for which the data were available the peripheral progesterone concentration decreased between the day of uterine traumatization (mean \pm s.e.m.: $6.86 \pm 1.17 \mathrm{ng} / \mathrm{ml})$ and the day before tissue sample collection $\left(3.52 \pm 0.97 \mathrm{ng} / \mathrm{ml}, t_{(10)}=4.53, P<\right.$ 0.002 ). The presence of an IUD or uterine traumatization had no effect on the peripheral progesterone concentration in animals with a corpus luteum $\left(F_{(1,31)}=4.02, P>0.05\right.$ and $F_{(1,31)}=3.49, P$ $>0.05$ respectively), or on the utero-ovarian vein concentration on the side ipsilateral to the corpus luteum $\left(\mathrm{F}_{(1,6)}=1.67, P>0.05\right.$ and $\mathrm{F}_{(1,6)}=1.78, P>0.05$ respectively). Baboon 155 had a low peripheral progesterone concentration and negligible concentrations in the utero-ovarian venous samples $(0.87$ and $0.88 \mathrm{ng} / \mathrm{ml})$, despite having had a gross structure in the left ovary identified as a corpus luteum at this time. Two other animals (Nos $156 \& 610$ ) had a low peripheral progesterone and low utero-ovarian venous progesterone concentrations on the final day when tissue samples were collected; presumably these 2 animals were in the later stages of luteal regression. In the remaining baboons progesterone concentration ranged from 118.8 to $975.8 \mathrm{ng} / \mathrm{ml}$ in the uteroovarian veins draining the corpus luteum-bearing ovary and 1.12 to $4.51 \mathrm{ng} / \mathrm{ml}$ in the contralateral vein. When the peripheral progesterone concentrations were indicative of a functional corpus luteum, the progesterone concentrations in the arterial and venous peripheral samples collected after hysterectomy and ovariectomy were invariably reduced to a mean concentration $37.5 \%$ of that before surgery.

There was no obvious difference between the treatment groups in the plasma oestradiol- $17 \beta$ concentrations (Table 2); the IUD and uterine traumatization had no significant effect on the peripheral concentrations $\left(\mathrm{F}_{(1,31)}=1.94, P>0.05\right.$ and $\mathrm{F}_{(1,31)}=2.85, P>0.05$ respectively) or on the concentration in the utero-ovarian vein ipsilateral to the corpus luteum $\left(\mathrm{F}_{(1,5)}=2.36, P>0.05\right.$ and $F_{(1,5)}=0.65, P>0.05$ respectively). Between the day of uterine traumatization and the day before tissue collection the mean ( \pm s.e.m.) peripheral oestradiol-17 $\beta$ concentration decreased from $87.80( \pm 11.47)$ to $63.94( \pm 8.00) \mathrm{pg} / \mathrm{ml}\left(t_{(10)}=2.98 ; P<0.02\right)$. In every animal in which a functional corpus luteum was deduced, the oestradiol- $17 \beta$ concentration in the utero-ovarian vein draining the corpus luteum-bearing ovary was higher (range: 1003-6897 $\mathrm{pg} / \mathrm{ml}$ ) than that of the contralateral vein $(175.0-223.9 \mathrm{pg} / \mathrm{ml})$. In Baboon 155 the peripheral oestradiol $-17 \beta$ concentration was low $(33 \mathrm{pg} / \mathrm{ml})$ but in the other animals the arterial and venous peripheral plasma concentrations after hysterectomy and ovariectomy were reduced compared to the preoperative sample, though the extent of the decrease (to $59.4 \%$ ) was not as great as that for progesterone concentrations $\left(t_{(18)}=3.52, P<0.01\right)$. 
Table 2. Peripheral and utero-ovarian plasma progesterone and oestradiol-17 $\beta$ concentrations in baboons with or without traumatized uteri and IUDs, and the locations of the corpora lutea $(R=$ right, $L$ $=$ left)

\begin{tabular}{|c|c|c|c|c|c|c|c|c|}
\hline \multirow[b]{2}{*}{ Treatment } & \multirow{2}{*}{$\begin{array}{l}\text { Baboon } \\
\text { no. } \\
\text { (CL) }\end{array}$} & \multicolumn{3}{|c|}{ Peripheral } & \multicolumn{2}{|c|}{$\begin{array}{l}\text { Utero-ovarian } \\
\text { venous }\end{array}$} & \multicolumn{2}{|c|}{$\begin{array}{l}\text { After hysterectomy + } \\
\text { ovariectomy, peripheral }\end{array}$} \\
\hline & & * & $\dagger$ & $\ddagger$ & Left & Right & Arterial & Venous \\
\hline Control & $\begin{array}{c}55(\mathrm{R}) \\
57(\mathrm{R}) \\
64(\mathrm{R} ?) \\
153(\mathrm{R})\end{array}$ & $\begin{array}{r}14.98 \\
7 \cdot 54 \\
5 \cdot 19\end{array}$ & $\begin{array}{r}\text { Proge } \\
\\
11.93 \\
0.16 \\
4.81\end{array}$ & $\begin{array}{r}\text { rone }(n \\
6.30 \\
11.47 \\
2.73 \\
3.91\end{array}$ & 4.51 & $\begin{array}{l}975 \cdot 8 \\
148 \cdot 1 \\
616 \cdot 9\end{array}$ & $\begin{array}{l}1.59 \\
1.82 \\
1.69 \\
2.66\end{array}$ & $\begin{array}{l}2 \cdot 35 \\
1 \cdot 57 \\
2 \cdot 32 \\
1 \cdot 62\end{array}$ \\
\hline $\begin{array}{l}\text { Traumatized } \\
\text { uterus }\end{array}$ & $\begin{array}{l}154(\mathrm{R}) \\
159(\mathrm{R}) \\
165(\mathrm{~L})\end{array}$ & $\begin{array}{l}2.44 \\
9.00\end{array}$ & $\begin{array}{l}1.88 \\
3.71\end{array}$ & $\begin{array}{l}1.53 \\
4.62 \\
8.06\end{array}$ & $\begin{array}{r}1 \cdot 86 \\
412 \cdot 4\end{array}$ & $156 \cdot 7$ & $\begin{array}{l}1.33 \\
1.69\end{array}$ & $\begin{array}{l}2.55 \\
2.08\end{array}$ \\
\hline IUD fitted & $\begin{array}{l}152(\mathrm{R}) \\
441(\mathrm{~L}) \\
610(\mathrm{R})\end{array}$ & $\begin{array}{r}7.68 \\
10.44 \\
5.79\end{array}$ & $\begin{array}{l}3 \cdot 19 \\
3 \cdot 87 \\
2 \cdot 80\end{array}$ & $\begin{array}{l}1.36 \\
3.56 \\
0.42\end{array}$ & $\begin{array}{c}1 \cdot 12 \\
118 \cdot 8 \\
0.59\end{array}$ & $\begin{array}{l}745 \cdot 0 \\
37 \cdot 35\end{array}$ & $\begin{array}{l}0.44 \\
0.84 \\
0.69\end{array}$ & $\begin{array}{l}0.50 \\
0.76 \\
0.72\end{array}$ \\
\hline $\begin{array}{l}\text { Traumatized } \\
\text { uterus, } \\
\text { IUD fitted }\end{array}$ & $\begin{array}{r}63(\mathrm{~L}) \\
155(\mathrm{~L}) \\
156(\mathrm{~L})\end{array}$ & $\begin{array}{l}7.04 \\
0 \cdot 60 \\
4 \cdot 77\end{array}$ & $\begin{array}{l}4 \cdot 75 \\
0 \cdot 45 \\
1 \cdot 16\end{array}$ & $\begin{array}{l}5 \cdot 02 \\
0.08 \\
0.42\end{array}$ & $\begin{array}{r}0 \cdot 87 \\
34-58\end{array}$ & $\begin{array}{r}0.88 \\
23 \cdot 29\end{array}$ & $\begin{array}{l}0.27 \\
0.55\end{array}$ & $\begin{array}{l}2.05 \\
0 \cdot 26 \\
0.48\end{array}$ \\
\hline Control & $\begin{array}{c}55(\mathrm{R}) \\
57(\mathrm{R}) \\
64(\mathrm{R} ?) \\
153(\mathrm{R})\end{array}$ & $\begin{array}{l}81 \cdot 38 \\
97 \cdot 77 \\
59 \cdot 47\end{array}$ & $\begin{array}{l}\text { Oestra } \\
\\
86 \cdot 88 \\
25 \cdot 42 \\
51 \cdot 33\end{array}$ & $\begin{array}{l}l-17 \beta \\
85.56 \\
82.39 \\
67.95 \\
61.92\end{array}$ & $175 \cdot 3$ & 6897 & $\begin{array}{l}34 \cdot 63 \\
40 \cdot 84 \\
43 \cdot 75 \\
41 \cdot 33\end{array}$ & $\begin{array}{l}42 \cdot 90 \\
43 \cdot 94 \\
42 \cdot 25 \\
47 \cdot 36\end{array}$ \\
\hline $\begin{array}{l}\text { Traumatized } \\
\text { uterus }\end{array}$ & $\begin{array}{l}154(\mathrm{R}) \\
159(\mathrm{R}) \\
165(\mathrm{~L})\end{array}$ & $\begin{array}{r}47.91 \\
70 \cdot 86\end{array}$ & $\begin{array}{l}56 \cdot 23 \\
62 \cdot 43\end{array}$ & $\begin{array}{l}50 \cdot 95 \\
63 \cdot 10 \\
78 \cdot 30\end{array}$ & $\begin{array}{l}223 \cdot 9 \\
3216\end{array}$ & 1003 & $\begin{array}{l}41.44 \\
58.89\end{array}$ & $\begin{array}{l}47 \cdot 09 \\
41 \cdot 30\end{array}$ \\
\hline IUD fitted & $\begin{array}{l}152(\mathrm{R}) \\
441(\mathrm{~L}) \\
610(\mathrm{R})\end{array}$ & $\begin{array}{l}79 \cdot 52 \\
149 \cdot 7 \\
161 \cdot 5\end{array}$ & $\begin{array}{c}59 \cdot 98 \\
97 \cdot 48 \\
110 \cdot 8\end{array}$ & $\begin{array}{l}55 \cdot 77 \\
78 \cdot 42 \\
75 \cdot 30\end{array}$ & $\begin{array}{c}175 \cdot 0 \\
1277 \\
183 \cdot 3\end{array}$ & $\begin{array}{l}2197 \\
841 \cdot 3\end{array}$ & $\begin{array}{l}43 \cdot 85 \\
48 \cdot 21 \\
38 \cdot 88\end{array}$ & $\begin{array}{l}33.95 \\
41 \cdot 56 \\
46 \cdot 20\end{array}$ \\
\hline $\begin{array}{l}\text { Traumatized } \\
\text { uterus } \\
\text { IUD fitted }\end{array}$ & $\begin{array}{r}63(\mathrm{~L}) \\
155(\mathrm{~L}) \\
156(\mathrm{~L})\end{array}$ & $\begin{array}{c}103 \cdot 5 \\
66 \cdot 43 \\
47 \cdot 73\end{array}$ & $\begin{array}{l}74 \cdot 36 \\
30 \cdot 46 \\
47 \cdot 99\end{array}$ & $\begin{array}{l}95.97 \\
33.00 \\
51.74\end{array}$ & $\begin{array}{c}64 \cdot 15 \\
709 \cdot 8\end{array}$ & $\begin{array}{l}162.5 \\
420.9\end{array}$ & $\begin{array}{l}47 \cdot 81 \\
26 \cdot 74\end{array}$ & $\begin{array}{l}45 \cdot 20 \\
38 \cdot 15 \\
32 \cdot 26\end{array}$ \\
\hline
\end{tabular}

* On day of uterine traumatization.

$\dagger$ On day before tissue collection.

$\ddagger$ On day of tissue collection.

\section{Prostaglandin concentrations}

The effect of the presence of an IUD and uterine traumatization on peripheral arterial and venous PG concentrations after hysterectomy was examined using the Student's $t$ test. The only significant difference was between the traumatized uterus and sham-operated groups in their arterial PGE-2 concentrations (mean \pm s.e.m., $0.90 \pm 0.10$ and $0.06 \pm 0.03 \mathrm{ng} / \mathrm{ml}$, respectively; $\left.t_{(2)}=8.04, P<0.05\right)$.

The utero-ovarian secretion of PGs is represented by the difference between the utero-ovarian vein concentrations and the arterial and peripheral venous concentrations after hysterectomy (Table 3), PGs being cleared from the circulation by the lungs and the hindquarters (Ferreira \& Vane, 1967). Although in every instance the PGE-2 and PGF- $2 \alpha$ concentrations were higher in the utero-ovarian venous samples than in the arterial and peripheral venous samples, except for PGE2 in one animal (No. 153), these differences were not significant $\left(t_{(5)}=1.63, P>0.05\right.$ and $t_{(10)}=$ $1 \cdot 66, P>0.05$ for the PGE-2 and PGF- $2 \alpha$ concentrations respectively). There was no significant 
Table 3. Endometrial, utero-ovarian venous, arterial and peripheral venous concentrations of PGE and PGF in baboons with or without traumatized uteri and IUDs

\begin{tabular}{|c|c|c|c|c|c|c|c|}
\hline \multirow[b]{3}{*}{ Treatment } & \multirow{3}{*}{$\begin{array}{c}\text { Baboon } \\
\text { no. }\end{array}$} & & & \multicolumn{4}{|c|}{ Plasma conc. (PGF-2 $\alpha \mathrm{ng} / \mathrm{ml})^{*}$} \\
\hline & & \multicolumn{2}{|c|}{$\begin{array}{c}\text { Endometrial } \\
\text { conc. }(\mathrm{ng} / 100 \mathrm{mg})\end{array}$} & \multicolumn{2}{|c|}{$\begin{array}{l}\text { Utero-ovarian vein } \\
\text { (before hysterectomy) }\end{array}$} & \multicolumn{2}{|c|}{$\begin{array}{l}\text { Peripheral } \\
\text { (after hysterectomy) }\end{array}$} \\
\hline & & PGE & PGF & Left & Right & Arterial & Venous \\
\hline \multirow[t]{4}{*}{ Control } & 55 & 0.23 & $10 \cdot 8$ & & 0.91 & 0.09 & 0.13 \\
\hline & 57 & $2 \cdot 2$ & 21.8 & & $10 \cdot 3$ & 0.18 & 0.35 \\
\hline & 64 & 0.8 & $5 \cdot 3$ & & & & \\
\hline & 153 & 0.86 & $9 \cdot 7$ & $\begin{array}{c}0.21 \\
(0 \cdot 34)\end{array}$ & $\begin{array}{c}0.45 \\
(0.47)\end{array}$ & $0 \cdot 26$ & $\begin{array}{c}0 \cdot 26 \\
(0 \cdot 66)\end{array}$ \\
\hline \multirow[t]{3}{*}{$\begin{array}{l}\text { Traumatized } \\
\text { uterus }\end{array}$} & 154 & $2 \cdot 0$ & $12 \cdot 1$ & $\begin{array}{c}1.43 \\
(1.43)\end{array}$ & $\begin{array}{l}1.07 \\
(1.07)\end{array}$ & & $\begin{array}{l}0.22 \dagger \\
(0.22) \dagger\end{array}$ \\
\hline & 159 & 0.7 & $8 \cdot 45$ & & & 0.17 & 0.21 \\
\hline & 165 & 0.3 & 3.06 & $(1.25)$ & $\begin{array}{c}0.96 \\
(2.2)\end{array}$ & $\begin{array}{c}0.28 \\
(0.8)\end{array}$ & $\begin{array}{c}0.19 \\
(0.85)\end{array}$ \\
\hline \multirow[t]{3}{*}{ IUD fitted } & 152 & $5 \cdot 1$ & $61 \cdot 1$ & $2 \cdot 4$ & $1 \cdot 78$ & $0 \cdot 1$ & $0 \cdot 15$ \\
\hline & 441 & $1 \cdot 34$ & $5 \cdot 2$ & $\begin{array}{r}0.121 \\
(0.07)\end{array}$ & & $\begin{array}{c}0.09 \\
(0.03)\end{array}$ & $\begin{array}{c}0.11 \\
(0.09)\end{array}$ \\
\hline & 610 & $23 \cdot 8$ & $75 \cdot 4$ & $\begin{array}{c}0.19 \\
(0 \cdot 21)\end{array}$ & $\begin{array}{c}0.53 \\
(0.37)\end{array}$ & $\begin{array}{l}0.08 \\
(0.09)\end{array}$ & $\begin{array}{c}0 \cdot 18 \\
(0 \cdot 26)\end{array}$ \\
\hline \multirow{3}{*}{$\begin{array}{l}\text { Traumatized } \\
\text { uterus, } \\
\text { IUD fitted }\end{array}$} & 63 & 7.9 & $2 \cdot 0$ & $\begin{array}{c}0.89 \\
(1 \cdot 15)\end{array}$ & & $\begin{array}{c}0.73 \\
(1.0)\end{array}$ & $\begin{array}{r}0.41 \\
(0.8)\end{array}$ \\
\hline & 155 & 3.7 & $62 \cdot 9$ & 0.22 & 0.26 & 0.12 & 0.28 \\
\hline & 156 & $1 \cdot 1$ & $50 \cdot 1$ & $2 \cdot 13$ & 1.45 & $0 \cdot 30$ & $0 \cdot 30$ \\
\hline
\end{tabular}

* Values in parentheses: PGE-2 conc. in $\mathrm{ng} / \mathrm{ml}$.

† Sample collected before hysterectomy.

variation in the utero-ovarian vein plasma concentrations of PGE-2 and PGF- $2 \alpha$ between the treatment groups.

The uterine endometrium concentrations of PGE and PGF were low in the control and traumatized uterus groups (ranges: $0 \cdot 23-2 \cdot 2$ and $3.06-21.8 \mathrm{ng} / 100 \mathrm{mg}$, respectively; Table 3) compared with the two IUD-bearing groups (ranges: $1 \cdot 1-23.8$ and $5 \cdot 2-75 \cdot 4 \mathrm{ng} / 100 \mathrm{mg}$, respectively); however, analysis of variance showed that the only significant effect was that of the presence of an IUD on the PGF concentration $\left(F_{(1,9)}=7.68, P<0.05\right)$. The maximum endometrial PGF concentration observed in the non-IUD-bearing baboons was $21.8 \mathrm{ng} / 100 \mathrm{mg}$; this concentration was exceeded in 4 of the 6 IUD-bearing baboons.

\section{Discussion}

The deciduomal reaction was stimulated in the baboons bearing an IUD, while the endometrial traumatization by the injection of arachis oil via the oviducts into the uterine lumen had no apparent effect on the histology of the uterine epithelium when examined 3-6 days later. These results are in contrast to those of Marston et al. (1971) who found that in the rhesus monkey traumatization of the uterine endometrium by oil injection alone stimulated a deciduomal reaction in 2 animals, one of which was given exogenous progesterone, and that an IUD alone failed to stimulate a deciduomal reaction except when exogenous progesterone or oil injection was administered. The presence of the IUD or the injection of arachis oil in the present experiment were not related to differences in the plasma progesterone and oestradiol-17 $\beta$ concentrations. Also, the steroid concentrations appear to have had no effect on the incidence of the deciduomal reaction. The observation of leucocytes in the uterine tissue from the IUD-bearing baboons supports the 
observations of leucocytes associated with the IUD in rhesus monkeys (Kelly, Marston \& Eckstein, 1969; Hurst, Jefferies, Eckstein, Dawson \& Wheeler, 1977).

The presence of the IUD, and therefore the incidence of the deciduomal reaction, was associated with increased PGF concentrations in the endometria compared with values in baboons with no IUD and no deciduoma. This finding is consistent with similar results obtained in the sheep (Wilson, Cenedella, Butcher \& Inskeep, 1972; Spilman \& Duby, 1972), guinea-pig (Poyser, Horton, Thompson \& Los, 1971), rabbit (Saksena \& Harper, 1974) and hamster and rat (Saksena, Lau \& Castracane, 1974), but in contrast to data from man in which the IUD had no effect on the uterine concentrations of PGF (Green \& Hagenfeldt, 1975; Hillier \& Kasonde, 1976; Scommegna et al., 1978). The IUD was associated with increased PGE concentrations in one human study (Hillier \& Kasonde, 1976), but these observations were made during the follicular (proliferative) phase of the menstrual cycle while the present samples were collected during the luteal (secretory) phase. The apparent contradiction between the human and the baboon PGF concentrations could be due to the fact that none of the human samples was collected with reference to the location of the IUD within the uterine lumen, and it has been shown in the sheep that the PG content is higher in the endometrium in contact with the IUD than in the remainder of the endometrium (Spilman \& Duby, 1972). Also, the human uterus is known to show spontaneous decidua-like changes during the luteal phase of the menstrual cycle when the progesterone concentration is high in the absence of any embryo (Edwards, 1980), and therefore the reports of Green \& Hagenfeldt (1975), Hillier \& Kasonde (1976) and Scommegna et al. (1978) may be comparing the PGF concentrations in human, non-IUD, decidualized uterine samples with IUD, decidualized samples collected from areas of the uterine endometrium not in contact with the IUD, while the present baboon study is comparing non-IUD, non-decidualized tissue with IUD, decidualized tissue that had been in contact with the IUD.

The lack of differences in the arterial and venous peripheral PGE-2 and PGF- $2 \alpha$ concentrations between the IUD and non-IUD baboons agrees with similar data obtained from women (Harrison, Scrivener \& Craft, 1974) and is to be expected from the known clearance of PGs by the lungs (Ferreira \& Vane, 1967).

The increased uterine tissue PG concentrations in the IUD-bearing baboons were not associated with increased PG concentrations in the single utero-ovarian venous plasma samples that we collected, presumably due to the episodic nature of PG release (Thorburn, Cox, Currie, Restall \& Schneider, 1972; Baird, Land, Scaramuzzi \& Wheeler, 1976). The increased uterine tissue PG concentrations had no effect on the progesterone and oestradiol-17 $\beta$ concentrations, confirming similar observation on steroid levels in IUD-bearing baboons (Tillson, Swisher, Pharriss, Erickson \& Neill, 1976) and rhesus monkeys (Hurst, Wheeler \& Eckstein, 1980). The lack of any effect of the IUD on luteal function in terms of progesterone secretion and the duration of the menstrual cycle has been reported earlier for baboons (Breed et al., 1972), women (Nygren \& Johansson, 1973) and rhesus monkeys (Eckstein et al., 1969). This suggests that either there is no mechanism for the utero-ovarian vein-to-ovarian artery transfer of PG in the baboon, although the requisite close anatomical relationship between the vein and the artery has been demonstrated in the rhesus monkey (Ginther et al., 1974), or that the baboon corpus luteum is insensitive to the luteolytic effects of PGs.

Conversely, the exposure of the uterus to low progesterone concentrations, especially in Baboons 610 and 156 in which luteal regression was judged to have been completed by the time of tissue collection and Baboon 155 which was judged not to have an active corpus luteum during the period monitored (Table 2), does not seem to have impaired the ability of the uterus to secrete PGs (Table 3).

It has been postulated that the antifertility effect of the IUD may be mediated by an increased local release of PGs (Chaudhuri, 1971; Thompson, 1973); the data reported here show that the endometrial samples from baboons bearing an IUD had higher concentrations of PGF. However, the role of the IUD-induced production of PGs in the antifertility action of the IUD has yet to be 
resolved (Williams \& Vane, 1975). Kennedy (1980) has suggested that in the rat an increase in the uterine endometrial PG synthesis is an integral part of the normal deciduomal reaction in that a mechanical stimulus causes an endometrium suitably primed by exposure to appropriate concentrations of oestrogen and progesterone to produce PGs; the increased PG concentrations stimulate the vascular permeability of the endometrium which precedes the onset of the deciduomal reaction. While the present data also support this theory, it is not clear how it relates to the antifertility effect of the IUD. Decidualization per se may not be involved in the contraceptive effect of IUDs; indeed some decidua-like changes are seen in the luteal-phase uterus during the normal menstrual cycle (Edwards, 1980).

The absence of any effect of the presence of the IUD on the peripheral steroid concentrations agrees with the observations of Breed et al. (1972) on the baboon and Martin \& Brown (1973), Nygren \& Johansson (1973) and Haukkamaa, Luukkainen \& Timonen (1974) on women. However, the difference between the IUD- and non-IUD-bearing animals in the presence or absence of a deciduomal response to the same steroid concentrations indicates that the IUD has altered the sensitivity of the endometrium to the prevailing oestradiol-17 $\beta$ and progesterone concentrations. Breed et al. (1972) and Nygren \& Johansson (1973) found that the onset of menstruation occurred earlier in the presence of an IUD, i.e. at a higher progesterone concentration, than in control cycles, indicating that the IUD modifies endometrial sensitivity to circulating steroids. Effects of the IUD on the deciduomal reaction in the mouse treated with oestrogen and progesterone regimens have been well documented (Martin \& Finn, 1979, 1980).

The decrease in the peripheral progesterone concentrations in the baboon samples collected on the day of endometrial traumatization until the day of tissue collection are characteristic of the concentrations and variation during the late luteal phase of the baboon menstrual cycle, as illustrated in Text-fig. 1 and described by Stevens et al. (1970), Breed et al. (1972), Albrecht \& Townsley (1976), Goncharov, Aso, Cekan, Pachalia \& Diczfalusy (1976) and Tillson et al. (1976).

When utero-ovarian samples were collected from both sides the plasma from the vein ipsilateral to a functional corpus luteum had higher progesterone concentrations, indicating that the main source of progesterone in the baboon is the corpus luteum. The range of concentrations of progesterone in the baboon ipsilateral vein was higher than that for rhesus monkeys (53.2-386.4 ng/ $\mathrm{ml}$ ) in the luteal phase (Weiss et al., 1973), although progesterone may be secreted by non-luteal ovarian tissue in the rhesus monkey (see Baird, 1977, for review). The rapid decrease in the peripheral progesterone concentrations after ovariectomy and hysterectomy, to $37.5 \%$ of the preoperative concentrations in about $30 \mathrm{~min}$, confirms that the ovaries are the major source of progesterone in the baboon.

The peripheral oestradiol- $17 \beta$ concentrations are similar to those shown in Text-fig. 1 and those measured during the luteal phase in the baboon (Goncharov et al., 1976; Tillson et al., 1976) and the rhesus monkey (Bosu, Holmdahl, Johansson \& Gemzell, 1972): utero-ovarian vein values were generally higher on the side ipsilateral to the corpus luteum, but on both sides the values were higher than those in peripheral blood. These data indicate that in the baboon during the late luteal phase the corpus luteum is the major source of oestradiol-17\%, while non-luteal ovarian tissue also secretes significant quantities of oestradiol-17 $\beta$. These data are in contrast to those reported by Weiss et al. (1973) for luteal-phase rhesus monkeys and by Bosu \& Johansson (1974) for hCGtreated rhesus monkeys.

We thank Mrs Kathryn Jefferies for assistance with the surgery and histological procedures; Mrs L. Simon for technical assistance; Miss A. Pelanis for help with the prostaglandin assays; Dr R. J. Scaramuzzi for the progesterone and oestradiol antisera; Mr H. Smith, Mr G. Tonks, Mr F. James and Mr R. Bryson for care of the animals; and the Ford Foundation for financial support (Grant number 630-0576B). 


\section{References}

Albrecht, E.D. \& Townsley, J.D. (1976) Metabolic clearance and production rates of progesterone in nonpregnant and pregnant baboons (Papio papio). Endocrinology 99, 1291-1294.

Baird, D.T. (1977) Synthesis and secretion of steroid hormones by the ovary in vivo. In The Ovary, 2nd edn, Vol. 3, pp. 305-357. Eds S. Zuckerman \& B. J. Weir. Academic Press, New York.

Baird, D.T., Land, R.B., Scaramuzzi, R.J. \& Wheeler, A.G. (1976) Endocrine changes associated with luteal regression in the ewe; the secretion of ovarian oestradiol, progesterone and androstenedione and uterine prostaglandin $\mathrm{F}_{2 \alpha}$ throughout the oestrous cycle. $J$. Endocr. 69, 275-286.

Blatchley, F.R. \& Poyser, N.L. (1974) The effect of oestrogen and progesterone on the release of prostaglandins from the uterus of the ovariectomised guineapig. J. Reprod. Fert. 40, 205-209.

Bosu, W.T.K. \& Johansson, E.D.B. (1974) Effect of HCG on plasma levels of estrogens and progesterone during the luteal phase of the menstrual cycle in rhesus monkeys (Macaca mulatta). Int. J. Fert. 19, 28-32.

Bosu, W.T.K., Holmdahl, T. H., Johansson, E.D.B. \& Gemzell, C. (1972) Peripheral plasma levels of oestrogens, progesterone and 17 $\alpha$-hydroxyprogesterone during the menstrual cycle of the rhesus monkey. Acta endocr., Copenh. 71, 755-764.

Breed, W.G., Stephenson, J.M., Eckstein, P., Peplow, P.V. \& Butt, W.R. (1972) Effect of an intrauterine device on menstrual cyclicity and luteal function in the baboon. J. Reprod. Fert. 28, 249-257.

Challis, J.R.G. \& Tulchinsky, D. (1974) A comparison between the concentration of prostaglandin $F$ in human plasma and serum. Prostaglandins 5, 27-31.

Chaudhuri, G. (1971) Intrauterine device: possible role of prostaglandins. Lancet i, 480.

Chaudhury, R.R. \& Sethi, A. (1970) Effects of an intrauterine contraceptive device on mitosis in the rat uterus on different days of pregnancy. J. Reprod. Fert. 22, 33-40.

Eckstein, P., Kelly, W.A. \& Marston, J.H. (1969) Effect of an intra-uterine device on menstrual periodicity in the rhesus monkey. J. Reprod. Fert. 19, 133-141.

Edwards, R.G. (1980) Conception in the Human Female. Academic Press, London.

Ferreira, S.H. \& Vane, J.R. (1967) Prostaglandins: their disappearance from and release into the circulation. Nature, Lond. 216, 868-873.

Ginther, O.J., Dierschke, D.J., Walsh, S.W. \& Del Campo, C.H. (1974) Anatomy of arteries and veins of uterus and ovaries in rhesus monkeys. Biol. Reprod. 11, 205-219.

Goncharov, N., Aso, T., Cekan, Z., Pachalia, N.\& Diczfalusy, E. (1976) Hormonal changes during the menstrual cycle of the baboon (Papio hamadryas). Acta endocr., Copenh. 82, 396-412.

Green, K. \& Hagenfeldt, K. (1975) Prostaglandins in the human endometrium. Am. J. Obstet. Gynec. 122, 611614.

Greenwood, B. \& Kerry, P.J. (1975) Prostaglandin production by a mild inflammatory lesion in sheep. $B r . J$. Pharmac. 53, 305-307.
Harrison, R., Scrivener, R. \& Craft, I. (1974) Serum prostaglandin $\mathbf{F}_{2 \alpha}$ levels and contraceptive techniques. Contraception 10, 535-541.

Haukkamaa, M., Luukkainen, T. \& Timonen, H. (1974) The effect of the Copper-T 200 IUD on the luteal phase plasma progesterone concentration in the normal menstrual cycle. Ann. clin. Res. 6, 40-44.

Hillier, K. \& Kasonde, J.M. (1976) Prostaglandin E and F concentrations in human endometrium after insertion of intrauterine contraceptive device. Lancet i, 15-16.

Hurst, P.R., Jefferies, K., Eckstein, P., Dawson, K. \& Wheeler, A.G. (1977) Leukocytes are consistently associated with degenerating embryos in IUD-bearing rhesus monkeys. Nature, Lond. 269, 331-333.

Hurst, P.R., Wheeler, A.G. \& Eckstein, P. (1980) A study of uterine embryos recovered from rhesus monkeys fitted with intrauterine devices. Fert. Steril. 33, 6976.

Kelly, W.A., Marston, J.H. \& Eckstein, P. (1969) Effect of an intra-uterine device on endometrial morphology and the deciduomal reaction in the rhesus monkey. J. Reprod. Fert. 19, 331-340.

Kennedy, T.G. (1980) Estrogen and uterine sensitization for the decidual cell reaction: role of prostaglandins. Biol. Reprod. 23, 955-962.

Marston, J.H., Kelly, W.A. \& Eckstein, P. (1971) Deciduomal reaction induced in rhesus monkeys by tubal injection of arachis oil and by the presence of an intrauterine device. J. Reprod. Fert. 25, 451-454.

Martin, L. \& Finn, C.A. (1970) The effects of an intrauterine device on uterine cell division and epithelial morphology during early pregnancy in the mouse. $J$. Endocr. 48, 347-354.

Martin, L. \& Finn, C.A. (1979) Varying effects of an IUD on decidualization in mice. $J$. Reprod. Fert. 55, 125133.

Martin, L. \& Finn, C.A. (1980) Effects of an intra-uterine device on uterine cell division and epithelial morphology in ovariectomized mice treated with oestrogen and progesterone. J. Endocr. 78, 417-425.

Martin, P.M. \& Brown, J.B. (1973) The effect of intrauterine contraceptive devices on ovarian and menstrual function in the human. J. clin. Endocr. Metab. 36, 1125-1131.

Nygren, K.-G. \& Johansson, E.D.B. (1973) Premature onset of menstrual bleeding during ovulatory cycles in women with an intrauterine contraceptive device. Am. J. Obstet. Gynec. 117, 971-975.

Poyser, N.L. \& Scott, F.M. (1980) Prostaglandin and thromboxane production by the rat uterus and ovary in sitro during the oestrous cycle. J. Reprod. Fert. 60, 33-40.

Poyser, N.L., Horton, E.W., Thompson, C.J. \& Los, M. (1971) Identification of $\mathrm{PGF}_{2 \alpha}$ released by distention of guinea pig uterus in vitro. Nature, Lond. 230, 526528.

Psychoyos, A. (1966) Recent researches on egg implantation. In Egg Implantation, (Ciba Fdn Study Gp, No. 23), p. 4. Eds G. E. W. Wolstenholme \& M. O'Connor. Churchill, London.

Rodbard, D. \& Lewald, J.E. (1970) Computer analysis of 
radioligand assay and radioimmunoassay data. Acta endocr., Copenh., Suppl. 147, 79-103.

Saksena, S.K. \& Harper, M.J.K. (1974) Prostaglandinmediated action of intrauterine devices: F-prostaglandins in the uterine horns of pregnant rabbits with unilateral intrauterine devices. Fert. Steril. 25, 121126.

Saksena, S.K., Lau, I.F. \& Castracane, V.D. (1974) Prostaglandin mediated action of IUD's (II) Fprostaglandins (PGF) in the uterine horn of pregnant rats and hamsters with intrauterine devices. Prostaglandins 5, 97-106.

Scaramuzzi, R.J., Corker, C.S., Young, G. \& Baird, D.T. (1975) Production of antiserum to steroid hormones in sheep. In Steroid Immunoassay, pp. 111-122. Eds E. H. D. Cameron, S. G. Hillier \& K. Griffiths. Alpha Omega Publishing, Cardiff.

Scommegna, A., Ilekis, J., Rao, R., Dmowski, W.P., Rezai, P. \& Auletta, F.J. (1978) Endometrial prostaglandin $F$ content in women wearing nonmedicated or progestin-releasing intrauterine devices. Fert. Steril. 29, 500-504.

Snedecor, G.W. \& Cochran, W.G. (1967) Statistical Methods, 6th edn, pp. 135-139. Iowa State University Press, Ames.

Spilman, C.H. \& Duby, R.T. (1972) Prostaglandin mediated luteolytic effect of an intrauterine device in sheep. Prostaglandins 2, 159-168.
Stevens, V.C., Sparks, S.J. \& Powell, J.E. (1970) Levels of estrogens, progestogens and luteinizing hormone during the menstrual cycle of the baboon. Endocrinology 87, 658-666.

Thompson, I.E. (1973) The IUD and prostaglandins: a review of the evidence. Obstet. Gynec. 42, 617-620.

Thorburn, G.D., Cox, R.I., Currie, W.B., Restall, B.J. \& Schneider, W. (1972) Prostaglandin F concentration in the utero-ovarian venous plasma of the ewe during the oestrous cycle. J. Endocr. 53, 325-326.

Tillson, S.A., Swisher, D.A., Pharriss, B.B., Erickson, R.E. \& Neill, J.D. (1976) Interrelationships between pituitary gonadotrophins and ovarian steroids in baboons during continuous intrauterine progesterone treatment. Biol. Reprod. 15, 291-296.

Weiss, G., Dierschke, D.J., Karsch,F.J., Hotchkiss, J., Butler, W.R. \& Knobil, E. (1973) The influence of lactation on luteal function in the rhesus monkey. Endocrinology 93, 954-959.

Williams, K.I. \& Vane, J.R. (1975) Inhibition of uterine motility: the possible role of the prostaglandins and aspirin-like drugs. Pharmacol. \& Ther. B 1, 89-113.

Wilson, L., Cenedella, R.J., Butcher, R.L. \& Inskeep, E.K. (1972) Levels of prostaglandins in the uterine endometrium during the ovine estrous cycle. J. Anim. Sci. 34, 93-99.

Received 10 March 1982 